
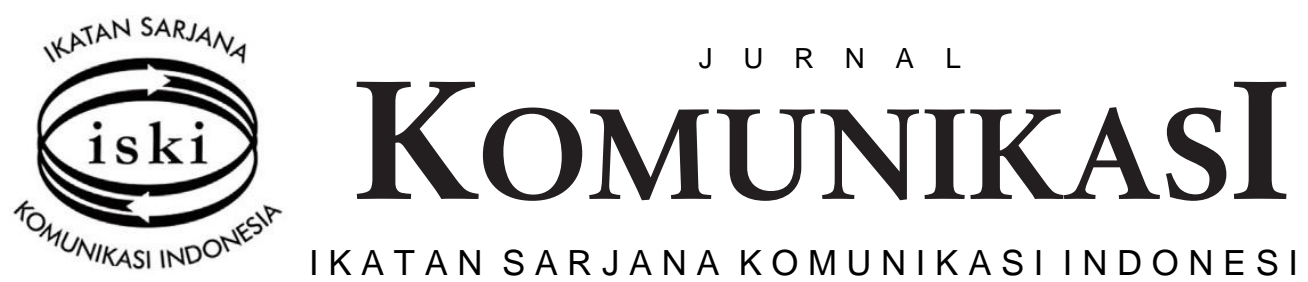

E-ISSN: 2503-0795

P-ISSN: 2548-8740

IKATANSARJANAKOMUNIKASI INDONESIA

\title{
Journalist Credibility Based on Digital Media Used
}

\author{
Suraya Suraya ${ }^{1^{*}}$ \\ ${ }^{1}$ Magister of Communication - Universitas Mercu Buana Jakarta \\ Jl. Meruya Selatan No. 1 Kembangan, Jakarta - Indonesia \\ *Corresponding author's email: suraya.suraya@mercubuana.ac.id
}

Submited: May 01, 2019, Revised: June 19, 2019, Accepted: June 26, 2019

Accredited by Kemristekdikti No. 30/E/KPT/2018

\begin{abstract}
This research studies the digital media consumption pattern of journalists. This consumption pattern is adopted by journalists to support their jobs. The work pattern of journalists in finding news fundamentally depends on the credibility of the sources. The process of choosing sources and finding ideas and information is usually done conventionally, but is presently done through social media. This study was conducted by surveying 60 journalists based in Jakarta. The method used for data analysis was descriptive statistics. The results of the research show that the vast majority of respondents had a high level of social media usage pattern; thus, it can be said that social media has a great influence on the work pattern of journalists. This can be seen from the vast majority of respondents who admitted that they had written about growing issues on social media as news in conventional media; they even admitted to interviewing some sources because they monitored their opinions and comments on social media. The type of journalists who became respondents in and around Jakarta (Jabodetabek) were creators, conversationalists and joiners; while the rest participated by consuming the social media and collecting information. Journalists in this position acted only as consumers.

Keyword: Digital Media, Journalist, Work Pattern, Credibility, Social Media
\end{abstract}

\begin{abstract}
Abstrak
Penelitian ini mengkaji mengenai pola konsumsi media digital yang dilakukan oleh para jurnalis. Pola konsumsi ini dilakukan oleh para jurnalis untuk menunjang pekerjaannya. Pola kerja jurnalis dalam mencari berita didasari pada prinsip kredibilitas nara sumbernya. Proses pemilihan nara sumber, mencari ide dan informasi biasanya dilakukan secara konvensional, maka saat ini dilakukan melalui media sosial. Kajian ini dilakukan menggunakan metode survey kepada para jurnalis di Jakarta berjumlah 60 orang. Teknik analisa data menggunakan statistik deskriptif. Hasil Penelitian menunjukan mayoritas responden memiliki pola penggunaan media sosial yang tinggi, maka pengaruh media sosial terhadap pola kerja jurnalis juga bisa dikatakan tinggi. Hal ini bisa dilihat dari mayoritas responden mengakui bahwa mereka pernah mengangkat isu yang berkembang di media sosial menjadi berita di media konvensional, bahka mereka juga mengakui pernah mewawancarai narasumber karena memonitor pendapat dan komentarnya di media sosial. Tipe jurnalis yang menjadi responden dan berada di Jabotabek adalah sebagai creators, conversationalist dan Joiners, sisanya berpartisipasi dengan mengkonsumsi media sosial dan mengkoleksi informasi. Para jurnalis pada posisi ini hanya berperan sebagai konsumen.
\end{abstract}

Kata Kunci: Digital Media, Journalist, Pola Kerja, Kredibilitas, Media Sosial 


\section{Introduction}

Media technology grows hand in hand with civilization growth. The concept of technological determinism depicts every happening or every action of humans to be influenced by the growth of technology.

The theory of Determinism by Marshall McLuhan (McLuhan, 1962) in his book The Gutenberg Galaxy: The Making of Typographic Man asserted that the changes that happen in the various methods of communication, will also shape the existence of humans themselves.

The changes in the age of communication after four previous stages, the Tribal Age, Literate Age, Print Age, and Electronic Age., have ushered a new age, the Electronic Age. This era was kick started by the invention of the world's first traditional telegraph by Samuel Morse that led to the emergence of more jaw-dropping electronic-based and computer-based communication products. The emergence of those electronic-based and computer-based communication products, also marked the invention of a lot of communication devices or technology such as the telegram, telephone, radio, film, television, VCR, fax, computer, and the internet (LittleJohn \& Foss, 2011).

Some people have felt the effects of the growth of technology. The way they consume information from media has changed. The growth of digital technology, that started around the nineties, has significantly influenced the process of consuming and producing media. As if digitalization has become the culture of society nowadays, one facet of it being the use of media for communication. The results of a study conducted by Morissan (Morissan, 2016) about the influence of television owners on program content in post authoritarian Indonesia show television owners control, directly or indirectly, television workers in shaping the program content. The indirect control was made through senior executives who hold strategic positions in the programming department and especially in the media editorial board. The owners sometimes get involved directly in shaping content, especially entertainment program. The owners used to come to a programming meeting where they lead and direct television workers. The owners evaluated the performance of the ongoing program and gave suggestions about what should be done to sustain the program success.

Another result of the research by Jamil (Jamil, 2018) showing the success of social movements in the disputes between the Corruption Eradication Commission (KPK) and the National Police (Polri), where the news reports in the media predominantly support the KPK, is not due to the success of social movement actors in approaching the media, but rather because of the congruence of values between the journalists and social movement actors.

The consumption pattern of digital media in each group of people can vary, depending on the needs and goals. A journalist as a media worker often also uses social media. The way the journalist uses the internet and social media can be seen from the survey conducted by Maverick and Paramadina University in 2013; only 1 out of 100 Indonesian journalists chose radio, and 5 out of 100 chose television as a source of news. The credibility of those media fell short when compared to online media and print media, which reached 54\% and 29\% respectively. Other findings said that even though social media has become one of the means to find journalistic ideas, the credibility is still questioned. Only 2 out of 10 Indonesian Journalists think of the social media as a trusted source of information. Even so, twitter, facebook and blogs became the most used social media by journalists in finding journalistic ideas (Maverick, 2013).

About trust and credibility on the online news media held by Sharon Wilson, the results of a research show youths still rely on traditional media to obtain news. However, traditional media fails to provide sufficient information for the youths so they resort to getting additional information from alternative news websites. Nevertheless, their level of trust in alternative news websites is based on how accurately these sites reflect the current scenario. Findings also reveal that students believe alternative news websites present different viewpoints. the trust extends to alternative online news sources but excludes blogs and the findings clearly show that the youths are not weaned off of traditional media (Wilson, Leong, Nge, \& Hong, 2011); The Credible Journalist in a digital age (Hayes, Singer, \& Ceppos, 2007); Journalist perceived online source credibility and verification behaviour (Vergeer, 2018); and Media Credibility (Srinivasan \& Barclay, 2017).

The results of a research carried out by Narayana Mahendra Prastya (Prastya, 2017) show that the activities of HRM by TopSkor newsroom are: developing the ability for their journalists, adding job obligations for their journalists, and recruiting new personnel for the online version. Profesional Research about female journalist in Kompas held by Ritonga (Ritonga, Murwani, \& Ritonga, 2017)

The research clarified that the internet, 
especially social media, has changed the work pattern of those journalists, especially in finding information and journalistic ideas from the internet. This phenomenon is interesting to be examined further - about the pattern of social media usage by the journalists. Based on the background of the problem that has been put forward, the problems of this research are as follow: What needs are the journalists searching for through digital media? What are the forms of digital media used by the journalists for their journalistic needs? What is the implication toward the overall work pattern of journalists? How far is the pattern of social media usage by the journalists in Indonesia?

\section{Theoretical Framework}

The concept of the pattern of information consumption discussed in this research referred to the technique or means of getting information through media. The interaction between individuals and communication media is the need of the individuals themselves. This is related to the communication pattern, done by someone in using communication media.

A study about media consumption was conducted by Leona Yi Fan Su. This study analyzes audiences' repertoires of science media consumption, and the effect of these consumption patterns on public understanding of science. ( $\mathrm{Su}$, Akin, Brossard, Scheufele, \& Xenos, 2015); How Young people consume News on Social Media (Boczkowski, Mitchelstein, \& Matassi, 2017)

Based on that explanation, human actions in finding information from media, is the communication process between humans and other components of communication - in this case (Lesmana, 2017) communication media. Use of communication media by humans is determined by technological aspect that keeps growing in every stage of civilization. The study about journalist professional versus employee - case of Koran Sindo in Censoring News on Trump' Travel Ban Policy was conducted by Tjipta Lesmana. Another research was held by Dendy Suseno about Influence of News Construction and netizen response to hoax news on the online media (Adhiarso, Utari, \& Hastjarjo, 2018). Research about news authorship and news sources was conducted by Ogadimma (Emenyeonu \& Mohamad, 2017).

Referring to the category of social technographic ladder@, made by forrester research Inc (Forrester, 2010) there are 7 types of activity of internet users. The category can be seen from the table below.

Table 1. Activity of Internet Users

\begin{tabular}{|c|c|}
\hline Creators & $\begin{array}{l}\text { Publish a blog } \\
\text { Publish your own web pages } \\
\text { Upload video you created } \\
\text { Upload audio/music you created } \\
\text { Write articles or stories and post them }\end{array}$ \\
\hline Critics & $\begin{array}{l}\text { Post rating/review of products or services } \\
\text { Comment on someone else's blog } \\
\text { Contribute to online forums } \\
\text { Contribute to/edit articles in a wiki }\end{array}$ \\
\hline Collectors & $\begin{array}{l}\text { Use RSS feeds } \\
\text { Vote for web sites online } \\
\text { Add tags to web pages or photos }\end{array}$ \\
\hline Joiners & $\begin{array}{l}\text { Maintain profile on a social networking } \\
\text { site } \\
\text { Visit social networking sites }\end{array}$ \\
\hline Spectators & $\begin{array}{l}\text { Read blogs } \\
\text { Listen to podcasts } \\
\text { Watch video from others users } \\
\text { Read online forums } \\
\text { Read customer rating/reviews }\end{array}$ \\
\hline Inactive & None of the above \\
\hline
\end{tabular}

Source: (Forrester, 2010)

Creators make social content go. They write blogs or upload video, music, or text. Critics respond to content from others. They post reviews, comment on blogs, participate in forums and edit wiki articles Collectors organize content for themselves or others using RSS feeds, tags, and voting sites like Digg.com.

Joiners connect in social networks like MySpace and facebook. Spectator, consumer social content including blogs, user generated video, podcasts, forum, or reviews. Inactives, neither create nor consumer social content of any kind.

The growth of technology, as with the concept of technological determinism by Marshall McLuhan, depicts every happening or every action of humans to be influenced by the growth of technology. McLuhan said, technology shapes individual in how they think, they act in society, and technology will lead human to progress from one age of technology to another. For example, from the tribal society which didn't know letters, to the society which used printing communication devices, to the society which used electronic communication devices. The essence of the theory of determinism is the finding or growth of communication technology is the factor which changed human culture. 
According to McLuhan, our culture is shaped by how we communicate (McLuhan M. , 2002).

The sophistication of communication technology in the electronic age eased the process of human communication. Indeed, in some condition, according to McLuhan, (McLuhan M. , Understanding Media: The Extension of Man, 1999), this electronic period is the most sophisticated period of the growth of human communication, replacing the previous period. McLuhan had also predicted technology would always progress with more advanced innovations. On top of that, humans would live in a global village. In the growth of communication technology, the concept of global village pictured every human in the world to live under one village. According to that definition, communication media in the present digital age, can bring humans to "touch" with other humans, whenever, wherever, and right at that moment.

Mitchell V Charnley (Charnley, 2007) defined news as "is the timely report of facts or opinion that hold interest and importance, or both, for a considerable of people." Based on the above definition for news, researchers understood, news is the information sought after by most people because it contains reports that hold interest and importance. News also has continuity, in which the continuity in this case - news is always delivered on-time.

Communication technology grows hand in hand with the growth of human civilization in communicating. The competence of communicating humans in communication technology consists of three things: (1) User, in which communicating humans as social scientist needs to be based on communication technology; (2) Content of technology, for example communication technology in the form of television or online media, then the ones who filled them are communicating humans. (3) Research of the social impact of communication technology. Communicating humans need to have the ability to research the social impact of communication technology, like researching the impact of technological progress to online media users.

New media theory is a theory developed by Pierre Levy (Straubhaar, LaRose, \& Davenport, 2014) who said that new media is a theory that discusses media growth. There are two views from the new media theory. First, the social interaction view that differentiates media with the closeness of eye-to-eye interaction.

New Media or social media such as website, Facebook, Instagram, Youtube, Line, WhatsApp,
Blog, Pinterest, etc.

The appearance of new media with all its forms and functions, will not be able to just replace the old or conventional media. This is in line with the categorization of communication technological advancement age that was done by Rogers (Schement \& Ruben, 2017) that the appearance of new media cannot just replace traditional media that is still needed by society to be a source of information according to their own characteristic.

Generally, according to Flemming, Hemingway, Moore and Welford (Fleming, Hemmingway, Moore, \& Welford, 2010), the work pattern of journalists is divided into three steps: (1) selecting news, (2) finding news, and (3) writing news.

Selecting news. In this step, the work function of journalists starts from selecting the news around them. This selecting process needs journalists' discernment to take potential newsworthy issues. Some media companies have their own rules in deciding which issues are newsworthy or not. In this case, journalists need to decide news that have news value. O'Neill, Deirdre and Tony Harcup (Harcup \& O'Neill, 2017) divided news value into some category: The power elite, Celebrity, Entertainment, Surprise, Bad news, good news, magnitude, relevance, follow-up, and newspaper agenda. News value becomes a reference for journalists in writing an issue.

The research conducted by Rasyid on news value shows the mass media provides extensive coverage over the visit because of its magnitude, proximity, prominence, and the unusualness values that the occasion has. (Rasyid \& Siagian, 2017); what makes "Good" News Newsworthy? The majority of "good" news stories were entertaining and emotional, whereas the majority of New York Times stories involved authority figures and conflict. Good news stories were less committed to journalism's core functions, such as holding power accountable and providing the public with information necessary for creating an informed electorate (McIntyre, 2016).

Finding news. In brief, Fleming et all (Fleming, Hemmingway, Moore, \& Welford, 2010) explained the steps of finding news, as a way for journalists to access information from news sources. News source, among others, comes from press release, newsroom diaries, emergency services, charities and pressure group, local government, trade organization, consumer groups, internet research, wire and email.

In the age of new media, it is possible for 
journalists to find information from the internet and pack it back into news. The age of new media made it possible for journalists to pick a different way of producing and distributing news, as explained by Becker and Vald (Becker \& Vlad, 2009) "the internet has changed much about the way news is produced and distributed. Journalists now can do their work in their work in their own and distribute their messages on their own."

The result of a research about finding news material also held by Rabia Noor showed that citizen journalism does not pose any imminent threat to mainstream journalism since it is just in its formative years. In fact, citizen journalism holds potential benefits as a source of news. It proves to be useful to bring to fore the stories that are inaccessible to professional journalists (Noor, 2017).

Writing News. This step is where journalists do the last process of journalistic work steps, before distributing it through the media. The thing that needs to be noticed by journalists, according to Fleming et all (Fleming, Hemmingway, Moore, \& Welford, 2010), is about the importance of the "human angle, facts, and balance" principle. This is a matter of the way journalists work in writing their news by emphasizing their humanity. News related to human interest or human's life are the most interesting news to the audiences. Here, the fact means "an event as it is that is seen and heard by journalists." The next principle is balance. Balance means "the way a journalist works that contains both parties of importance so justice can be gained."

Newspapers have transformed in functions and style such that they no longer deliver firstinstance news reporting, but serve as an analytical and/or in-depth complement to the more immediate, instantaneous online news outlets. Broader implications of the findings including theoretical connections to comparative media systems, medium theory, and professional role conceptions of journalists are discussed (Tanikawa, 2017).

\section{Material and Methodology}

To find out the pattern of digital media usage of journalists in Indonesia, this research chose positivist paradigm. Moreover, this research used quantitative approach. The method used in quantitative research was the descriptive survey method.

Part of or the overall objects or phenomena that would be observed was mass media workers, both electronic and press in Jakarta - for a total of 60 respondents. Sampling technique used was purposive sampling. This research used questionnaire as a means of measuring the data. Data analysis technique used was descriptive statistic: Frequencies Table.

\section{Results and Discussion}

A research showed more men than women were employed as media workers, with 38 compared to 22 . The usage of social media by journalists was quite high - more than 10 times everyday (70\%). Respondents said they spent more than 6 hours a day using the social media (27\%), while the rest spent 36 hours a day (43\%). On average every journalist has 3-4 social media (52\%). This showed that the use of social media is now inseparable from the daily life and work pattern of journalists.

Whether consciously or not, journalists also use social media on their daily work. The work pattern of journalists starts from finding information from sources, publishing information or just having communication, to holding discussion with other people through social media. This can be seen from the result of the research that showed journalists tend to write issues on social media as news in traditional media. Most journalists answered they had done so $(83 \%)$. A lot of journalists also wrote issues from social media to traditional media (83\%). On top of that, journalists also had done interviews through social media and publish it on traditional media. This showed that journalists trusted the sites they read on digital/social media. Journalists assumed that the work pattern of those news sites has passed through a series of flows of news, thus the news sites or social media they read and quoted could be trusted (having a high credibility).

The results of the research also showed the social category that served as the type of the journalists to become respondents:

Table 2. Journalists Types

\begin{tabular}{lll}
\hline \multicolumn{1}{c}{$\begin{array}{c}\text { Activity of journalists in } \\
\text { social media }\end{array}$} & $\begin{array}{c}\text { Activity } \\
\text { type }\end{array}$ & f \\
\hline $\begin{array}{l}\text { Uploading works to social } \\
\text { media accounts or blogs or }\end{array}$ & & \\
private website & & 98 \\
\hline $\begin{array}{l}\text { Only reading forums, or blogs, Spectators } \\
\text { or friends' status updates in } \\
\text { social media, watching } \\
\text { video/film and listening to } \\
\text { music }\end{array}$ & \\
\hline $\begin{array}{l}\text { Updating status in social } \\
\text { media accounts }\end{array}$ & $\begin{array}{l}\text { Conversatio } \\
\text { nalist }\end{array}$ & \\
\hline $\begin{array}{l}\text { Activating RSS to collect } \\
\text { information }\end{array}$ & Collectors & \\
\hline
\end{tabular}




\begin{tabular}{lll}
\hline $\begin{array}{l}\text { Making a private social media } \\
\text { account and visiting others' } \\
\text { social media account }\end{array}$ & & \\
\hline $\begin{array}{l}\text { Commenting on others' social } \\
\text { media account }\end{array}$ & Critics & 95 \\
\hline
\end{tabular}

Source: Questionnaire

At present, journalists are very active in using social media. Based on their activities, most of journalists are divided into three types: Creators, Conversationalists, and Joiners. Only a few journalists are either collectors or critics. It can be concluded that journalists are active in contributing information by publishing their articles online. Meanwhile, the rest only consumes and collects information from social media. This type of journalists only acts as consumers.

Table 3. Needs Fulfilled by Social Medias

\begin{tabular}{|c|c|}
\hline Needs fulfilled by Social Medias & $\mathbf{f}$ \\
\hline $\begin{array}{lll}\begin{array}{l}\text { Building } \\
\text { friendship }\end{array} & \text { relation/ relationship/ } \\
\end{array}$ & 97 \\
\hline $\begin{array}{lll}\begin{array}{l}\text { Discussing } \\
\text { information }\end{array} & \text { and exchanging } \\
\end{array}$ & 93 \\
\hline News/ information update & 95 \\
\hline Obtaining knowledge & 88 \\
\hline Nurturing personal skills & 79 \\
\hline Entertainment & 85 \\
\hline Showing one's worth & 73 \\
\hline Showing personal status & 70 \\
\hline
\end{tabular}

Source: Questionnaire

From the results of the discussion above, journalists used social media too much for building relations, including those with sources. These networking skills showed the excellence of journalists in that they could have access to and network with the parties that became their sources. This is also seen from the needs for discussion and information exchange related to news/information update. This is the result of the opening of access and network through social media.

Table 4. Social Media Usage for Journalist Social Media Usage of Journalistic Job

\section{F}

Finding data or information

(texts, pictures) 98

Finding out current issues which catch the public's eyes 96

Finding ideas for news 87

Monitoring the development of issues

\begin{tabular}{|c|c|}
\hline data/information & 85 \\
\hline Posting written articles & 82 \\
\hline $\begin{array}{l}\text { Discussing about issues with } \\
\text { other journalists }\end{array}$ & 78 \\
\hline Identifying opinion of figures & 75 \\
\hline
\end{tabular}

The results of the research show that social media influenced the entire work pattern of journalists in Jakarta. This process started from finding news sources, both events and people's opinions, selecting news sources, to writing and publishing news stories. The results of the research show that social media is used to find data or information (98\%) and monitor developments or issues $(98 \%)$. Also, social media is used to find current issues to write eye-catching news. This type of journalists utilized social media to get documents, either information, photo, or news-related pictures, from the data that have been uploaded by someone else. In the stage of selecting news, the journalists also utilized social media to get news ideas, find the current issues to write eye-catching news and monitor the developments.

Of course, the issues written by the journalists were newsworthy. The issues from social media were those followed up on by the journalists. The result can be seen from list 1.5 below

Table 5. Issues followed up from social media Issues followed up from social

\begin{tabular}{lc}
\multicolumn{1}{c}{ media } & F \\
\hline $\begin{array}{l}\text { Shocking and unexpected events } \\
\text { (disasters, etc.) }\end{array}$ & 98 \\
\hline $\begin{array}{l}\text { Issues concerning public interests } \\
\text { (price increase of electricity, }\end{array}$ & 98 \\
gasoline, healthcare, etc) & 85 \\
\hline $\begin{array}{l}\text { Figures, institutions, or famous } \\
\text { people }\end{array}$ & 95 \\
\hline $\begin{array}{l}\text { Updates or the continuation of } \\
\text { previous news }\end{array}$ & 87 \\
\hline $\begin{array}{l}\text { Hobby, funny stories, community, } \\
\text { etc light and amusing information }\end{array}$ & 83 \\
\hline $\begin{array}{l}\text { Achievement, accomplishment, and } \\
\text { positive things about someone }\end{array}$ & 73 \\
\hline $\begin{array}{l}\text { Scandals and bad things that happen } \\
\text { to someone }\end{array}$ & 70 \\
\hline
\end{tabular}

Source: Questionnaire

The results of the research above show the issues that have high news value and come under the spotlight are those related to unexpected/shocking events and those concerning public interests. Based 
on Habermas' opinion regarding public spaces, a lot of people nowadays use digital media in this case social media to share the problems that happen in society. Because of that, right now people tend to be citizen journalists that report ongoing events as the parties that are on the scene of the events. Journalists just have to monitor the development of issues on unexpected events like flood or other natural disasters. Social media become invaluable sources for journalists to observe and monitor these events.

The work pattern of journalists has been researched by Santoso and Budianto too (Santoso \& Budianto, 2016). Firstly, internet-based television differs from standard conventional television, the use of human resources is diminished to lessen the production and post-production cost. Secondly, the management of informative content deals not only with the process of content production but also with the virtual-based distribution strategy. Lastly, a slim structure and a creative culture successfully produce a variety of creative programs because it is supported by youths familiar with digital technology.

Social media gives anyone the chances to connect and interact. Through social media, audiences and journalists can interact in an interactive, easy, and relatively cheap way. Journalists can also have access to and establish network with other people, especially their sources. Content or information found on social media is very abundant - overloading, even. In this regard, journalists still need to make sure the credibility of their sources. Because of that, they still have to thoroughly check or verify all information sources from social media. This kind of thing was also indicated by the results of a research conducted by Mulyana and Morissan (Mulyana \& Morissan, 2015) who also conducted a research on the use of the Internet and social media.

The results of the research show that: (1) The average percentage of news commentary assessed manners is 74 percent, while the average percentage of news comments judged to be polite is 26.3 percent; (2) The 74 percent for comments considered polite indicates that the new media audience, especially visitors of portal news in Indonesia has a relatively good level of politeness; (3) Based on data obtained from the three coders in the study, the average percentage of news comments judged to be polite is 26.3 percent. Thus, the level of news portal visitors' politeness in Indonesia is categorized as a courtesy.

\section{Conclusion}

The vast majority of respondents have a high pattern of social media usage, thus the influence of social media on the work pattern of journalists is also high. This can be seen from the vast majority of respondents admitting they had written issues developing in social media in conventional media. Moreso, they admitted too that they had interviewed sources because they monitored their opinions and comments on social media. The types of journalists that became respondents and were based in and around Jakarta (Jabodetabek) are creators, conversationalists, and joiners, while the rest participated by consuming social media and collecting information. Journalists in this position only acted as consumers.

The presence of social media caused communication patterns between journalists, sources and media management as well as audiences. In addition, social media also spawned citizen journalists that report events that happen around them, so they became the source of data that journalists use for the news they work on.

The recommendation of this research is that to face the onslaught of information through social media, journalists need to also become a gatekeeper by ensuring the credibility of the news they write and checking or verifying thoroughly all sources of information they obtain from social media.

\section{References.}

Adhiarso, D. S., Utari, P., \& Hastjarjo, S. (2018). The Influence of News Construction and Netizen Response to The Hoax News in Online media. Jurnal The Messenger (Culture Studies, IMC and Media , 10 (2), 162-173.

Becker, L. B., \& Vlad, T. (2009). News Organizations and Routines (Vol. 1). (K. wahl-Jorgensen, \& T. Hanitzsch, Eds.) New York, Amerika, Amerika: Routledge.

Boczkowski, P. J., Mitchelstein, E., \& Matassi, M. (2017). Incidental News: How young People Consume News on Social Media. Proceedings of the 50th Hawaii International Conference on System Sciences (pp. 1785-1792). Amerika: scholarspace.manoa.hawaii.edu.

Charnley, M. V. (2007). News By Radio. New York, Amerika, Amerika: Macmillan Company.

Emenyeonu, O. C., \& Mohamad, B. (2017). News Authorship and News Sources: Impacts on environmental Coverage in Nigerian Press. Jurnal The Messenger , 9 (2), 110-119. 
Fleming, C., Hemmingway, E., Moore, G., \& Welford, D. (2010). An Introduction to Journalism. London, Inggris, Inggris: Sage Publications.

Forrester, R. (2010, October 20). Kategori Sosial Technographic Ladder@. Retrieved November 27, 2017 from Forrester Research.com: http://empowered.forrester.com/ladder2010/) Harcup, T., \& O'Neill, D. (2017). What is News, News Values Revisited (again). Journal of Journalism Studies , 18 (12), 1470-1488.

Hayes, A. S., Singer, J. B., \& Ceppos, J. (2007). Shifting Roles, enduring Values: The Credible Journalist in a Digital Age. Journal of Mass Media Ethics , 22 (4), 262-279.

Jamil, A. (2018). Social Movement in Framing Perspectives: A Study on Corruption Case Issue in Indonesia. Jurnal Komunikasi Indonesia , 7 (2), 174-191.

Lesmana, T. (2017). Journalist as Professional versus Employee - a Case of Daily Koran Sindo in Censoring News on Trump's Travel - Ban Policy. Jurnal Komunikasi Ikatan Sarjana Komunikasi Indonesia, 2 (2), 109-119.

LittleJohn, S. W., \& Foss, K. A. (2011). Theories of Human Communication (Vol. 10). New York, Amerika, Amerika: Waveland Press.

Maverick. (2013, Januari). Indonesian Journalist Technographics. Retrieved November 27, 2017 from Maverick.co.id: http://www.maverick.co.id/journalists/2013/_ 01/indonesia-journalists-technographics-fullreport/

McIntyre, K. (2016). What Makes "Good" News Newsworthy? Communication Research Reports , 33 (3), 223-230.

McLuhan, M. (1962). The Guttenberg Galaxy: The Making of Typographic Man. London, Inggris: The MIT Press.

McLuhan, M. (1999). Understanding Media: The Extension of Man. London, Inggris, Inggris: The MIT Press.

McLuhan, M. (2002). Media Performance: Mass Communication and Public Interest. London, Inggris, Inggris: Sage Publication.

Morissan. (2016). The Influence of Television Owners on Program Content in Post Authoritarian Indonesia. Intrenational Journal of Humanities \& Social Science Studies (IJHSSS) , 3 (3), 149-173.

Mulyana, A., \& Morissan. (2015). Civility on Social Media (The Tendency of Politeness Level of
Internet Users on Soscial Media. Jurnal Visi Komunikasi , 13 (1), 69-86.

Noor, R. (2017). Citizen Journalism VS Mainstream Journalism: A Study on Challenges Posed by Amateurs. Athens Journal of Mass Media and Communications , 3 (1), 55-76.

Prastya, N. M. (2017). Media Convergence and Human resources Management in Sport Media Newsroom - Case Study at Daily TopSkor. Jurnal Komunikasi Ikatan Sarjana Komunikasi Indonesia, 2 (2), 57-64.

Rasyid, A., \& Siagian, H. F. (2017). News Value and Reality: Case Study. Jurnal Komunikasi Malaysian Journal of Communication, 33 (3), 55-69.

Ritonga, R., Murwani, E., \& Ritonga, S. (2017). Gender Awareness of Maria Hartiningsih as Daily Kompas Reporter. Jurnal Komunikasi Ikatan Sarjana Komunikasi Indonesia, 2 (2), 82-91.

Santoso, D. H., \& Budianto, H. (2016). Penerapan New Media Technology pada Televisi Berbasis Internet Solo Pos TV (2013-2015). Jurnal Visi Komunikasi , 15 (1), 79-95.

Schement, J. R., \& Ruben, B. D. (2017). Between Communication \& Information; Information \& Behavior (Vol. 4). New York, Amerika, Amerika: Routledge, Taylor \& Francis Group.

Srinivasan, M., \& Barclay, F. P. (2017). Media Credibility: A Triangulation Test. Journal of Content, Community \& Communication , 6 (3).

Straubhaar, J., LaRose, R., \& Davenport, L. (2014). Media Now; Understanding Media, Culture and Technology (Vol. 8). Boston, Amerika, Amerika: Wadsworth, Cengage Learning.

Su, L. Y.-F., Akin, H., Brossard, D., Scheufele, D. A., \& Xenos, M. A. (2015). Science News Consumption Pattern and Their Implication for Public Understanding of Science. Journalism \& Mass Communication Quarterly, 92 (3), 597-616.

Tanikawa, M. (2017). What Is News? What Is The Newspaper? The Physical, Functional, and Stylistic Tranformation of Print Newspaper, 1988-2013. International Journal of Communication, 11, 3519-3540.

Vergeer, M. (2018). Incorrect, Fake and False. Journalists' Perceived Online Source Credibility and Verification Behavior. Observatorio J(OBS*) ournal , 37-52.

Wilson, S., Leong, P., Nge, D. C., \& Hong, D. N. (2011). trust and Credibility of Urban Youth 
on Online News Media. Jurnal Komunikasi

Malaysian Journal of Communication , 27 (2), 97-120. 